\title{
Eco-friendly biosynthesis, anticancer drug loading and cytotoxic effect of capped Ag-nanoparticles against breast cancer
}

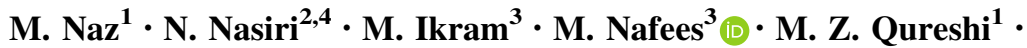

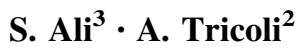

Received: 14 August 2017/ Accepted: 4 October 2017/Published online: 23 October 2017

(C) The Author(s) 2017. This article is an open access publication

\begin{abstract}
The work aimed to prepare silver nanoparticles (Ag-NPs) from silver nitrate and various concentrations of the seed extract (Setaria verticillata) by a green synthetic route. The chemical and physical properties of the resulting Ag-NPs were investigated by X-ray diffraction (XRD), transmission electron microscopy (TEM), Fourier transform infrared (FTIR) spectrometry and ultraviolet-visible (UV-Vis) spectrophotometry. Anticancer activity of AgNPs $(5-20 \mathrm{~nm})$ had dose-dependent cytotoxic effect against breast cancer (MCF7-FLV) cells. The in vitro toxicity was studied on adult earthworms (Lumbricina) resulting in statistically significant $(P<0.05)$ inhibition. The prepared NPs were loaded with hydrophilic anticancer drugs (ACD), doxorubicin (DOX) and daunorubicin (DNR), for developing a novel drug delivery carrier having significant adsorption capacity and efficiency to remove the side effects of the medicines effective for leukemia chemotherapy.
\end{abstract}

M. Ikram

dr.muhammadikram@gcu.edu.pk

$\triangle$ M. Nafees

rajvi_gcu@yahoo.com

1 Biochemistry Lab, Department of Chemistry, Government College University Lahore, Lahore 54000, Pakistan

2 Nanotechnology Research Laboratory, Research School of Engineering, Australian National University, Canberra 2601, Australia

3 Solar Cell Applications Research Lab, Department of Physics, Government College University Lahore, Lahore 54000, Pakistan

4 Institute for Biomedical Materials and Devices, Faculty of Science, University of Technology Sydney, Sydney 2007, Australia
Keywords Drug loading · Seed extract · Cytotoxicity · Anthelmintic activity $\cdot$ Ag-NPs

\section{Introduction}

Nobel metal nanoparticles (NPs) such as silver (Ag), gold $(\mathrm{Au})$ and platinum $(\mathrm{Pt})$ have attracted significant attention due to their potential medicinal properties for use as sensor and for biomedical imaging (Zhang et al. 2017; Zhang et al. 2016). Among these, Ag-NPs have unique optical, electrical and biomedical properties, making them suitable for biosensing, imaging and catalysis, as medicine and in nano device fabrication and drug delivery (Ismail et al. 2017; Lee and El-Sayed 2006; Nair and Laurencin 2007; Upendra et al. 2015). There is a growing demand to develop eco-friendly methods, which are free from toxic substances, for the synthesis of NP (Lade and Patil 2017; Smetana et al. 2005; Yu 2007; Zhang et al. 2009). Various techniques have been used to prepare Ag-NPs such as thermal decomposition, chemical reduction, microwaveassisted synthesis, biological reduction and laser-mediated synthesis (Navaladian et al. 2007; Krishna et al. 2016; Tolaymat et al. 2010; Zamiri et al. 2011). Among these, biosynthesis employs significantly lower quantities of toxic chemicals and thus provides an attractive alternative for the synthesis of environmentally benign nanoparticles.

Various research groups have explored the role of seed extracts from different plants such as Linum usitatissimum L., Artocarpus heterophyllus lam., Cola nitida, pomegranate, Elettaria cardamomum, Melia azedarach and Medicago sativa (Azeez et al. 2017; Lukman et al. 2011; Kokina et al. 2013; Khan et al. 2011; Jagtap and Bapat 2013) for the biosynthesis of environment-friendly AgNPs. Recently, a green eco-friendly route was employed 
Fig. 1 Molecular structure of DOX and DNR

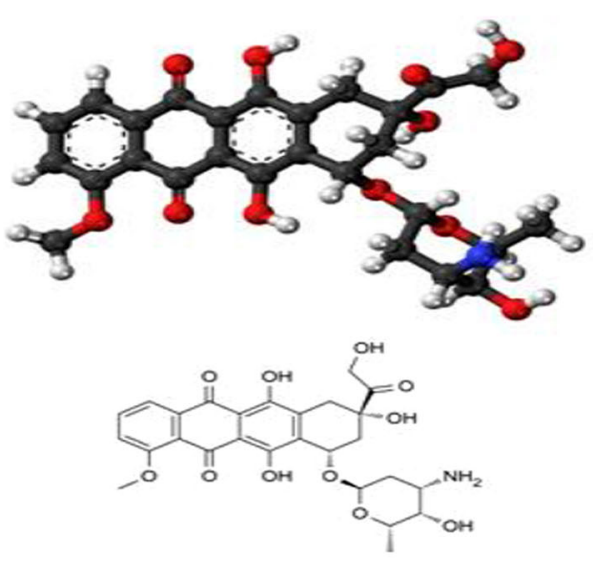

Doxorubicin
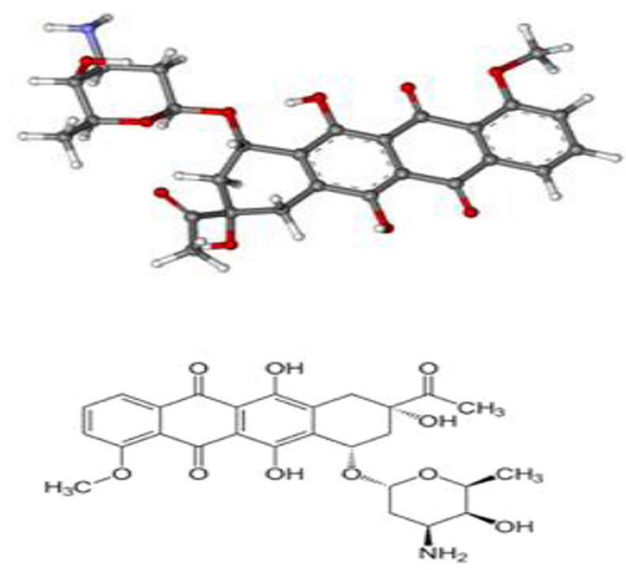

Daunorubicin for the synthesis of stable NPs using the extracts derived from Setaria verticillata seeds. Setaria verticillata is a grassy annual plant that belongs to the family of Poaceae. Historically, it has found different purposes in different regions such as preparing malt for beer in South Africa, making porridge in Nambia and as nutritious and palatable forage for livestock (Holm et al. 1977).

Since the last decade, nanoparticles-based drug loading has gained the attraction of researchers due to its potential to reduce the expected side effect produced by conventional methods. UV-visible spectroscopy is the most convenient, economical, accurate and extensively used method to estimate drug loading. In this study, Ag-NPs with various concentrations of the seed extract (Setaria verticillata) were prepared by a green synthetic route. The cytotoxicity was evaluated against MCF7-FLV breast cancer cells, and in vitro anthelmintic screening of NPs was performed on adult earthworms as model due to their physiological and anatomical resemblance to human intestinal parasites. In addition, NPs were used for anticancer drug (ACD), DOX and DNR, loading. Here, a variety of techniques, including XRD, TEM, FTIR spectrometry and UV-Vis spectroscopy were used to characterize the biosynthesized Ag-NPs as a function of the concentration of Setaria verticillata seed extract.

\section{Materials and methods}

\section{Materials}

Silver nitrate was obtained from Sigma-Aldrich. The MCF7-FLV1000 cell was provided by the Department of Cancer Biology and Therapeutics, John Curtin School of Medicine, Australian National University (ANU). Anticancer drugs doxorubicin hydrochloride [DOX, Pharmedic Laboratories (Pvt.) Ltd] and daunorubicin [DNR, Pharmedic Laboratories (Pvt.) Ltd] were used for drug loading.
Setaria verticillata seeds were collected from the Mozang region in Lahore, Pakistan, and identified at the Department of Botany Government College University (GCU) Lahore, Voucher No. GC.Herb.Bot.2914. Adult earthworms (Lumbricina) were collected locally from River Ravi region Lahore. The identification of Lumbricina was done according to standard methods (Sims and Gerard 1985). The earthworm's body was cylindrical in shape and the posterior end was flattened dorsoventrally. The body length of the adult earthworm ranged between 100 and $300 \mathrm{~mm}$ and the diameter varied between 2 and $6 \mathrm{~mm}$. External transverse furrows dividing the body into a series of similar linear compartments were also present on the earthworm's body. Figure 1 represents the structure of anticancer drugs used in the experiment (Doxorubicin 2017; Daunorubicin 2017).

\section{Preparation of plant extract and synthesis of Ag-NPs}

Setaria verticillata (SV) seeds were cleaned using distilled water three times prior to use. $10 \mathrm{~g}$ of seeds was dipped in $100 \mathrm{ml}$ of double distilled water for $24 \mathrm{~h} \mathrm{(h).} \mathrm{The} \mathrm{aqueous}$ $\mathrm{SV}$ extract was filtered and then kept in the refrigerator for further experiments (Sharma and Jeevanandam 2013). For the preparation of Ag-NPs, different concentrations of SV extract, namely 10 vol\% (10 SV), 20 vol\% (20 SV), $30 \mathrm{vol} \%$ (30 SV) and 40 vol\% (40 SV), were mixed with $1 \mathrm{mM}$ aqueous $\mathrm{AgNO}_{3}$ solution, in which $\mathrm{AgNO}_{3}$ was reduced by the $\mathrm{SV}$ extract. The reduction of $\mathrm{Ag}^{+}$was confirmed by a distinct change of color as shown in Fig. 2a.

\section{Particle characterization}

UV-visible spectrophotometer (TECAN infinite M200PRO) was used to monitor the absorption spectra of various concentrations of Ag-NPs. The mean crystal size, phase composition and other structural information of $\mathrm{Ag}$ - 
Fig. 2 a Setaria verticillata seeds. b Visual appearance of vials containing seed extract and different concentrations of SV seed extract, from 10 up to 40 vol\% (left to right), mixed with $1 \mathrm{mM}$ silver nitrate. c UVvisible absorption spectra for seed extract and different concentrations of extract from $10 \mathrm{vol} \%$ (10 SV) up to $40 \mathrm{vol} \%$ (40 SV) in making Ag-NPs
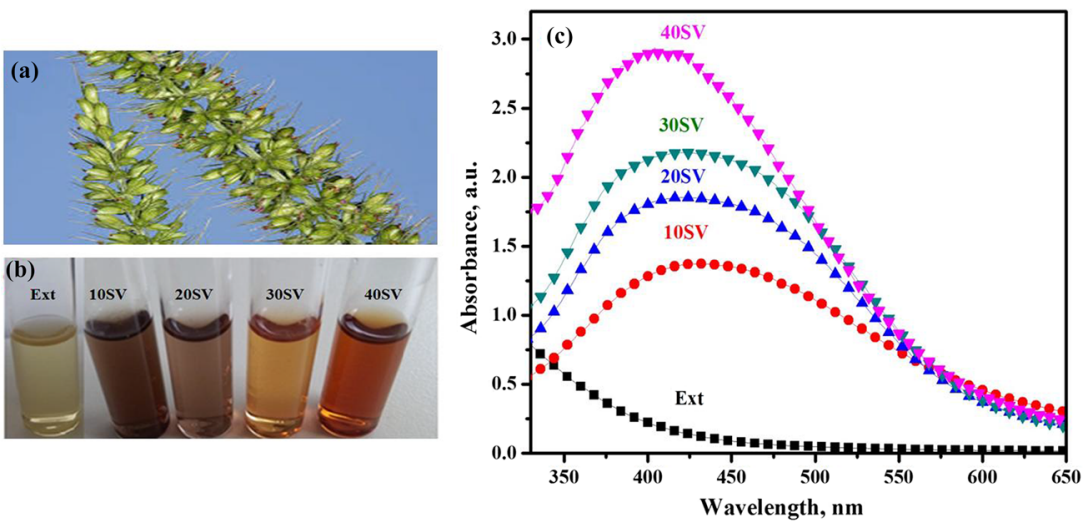

NPs were obtained by XRD using Bruker system (XRD, D2 Phaser, USA) equipped with $\mathrm{Cu} \mathrm{K} \alpha$ radiation of average wavelength $1.54059 \AA$. The size distribution of AgNPs was characterized by TEM using Hitachi H7100FA TEM at $100 \mathrm{kV}$. Energy-dispersive X-ray spectroscopy (EDX) analysis was also conducted using Hitachi H7100FA TEM. The functional groups in the resultant samples were investigated using BRUKER ALPHA Platinum ATR spectrometer.

\section{Neutral red assay}

MCF7-FLV1000 cells were routinely seeded in media (RPMI) supplemented with $10 \%$ fetal bovine serum (FBS), $10 \mathrm{mM}$ HEPES and $2 \mathrm{~g} / \mathrm{L} \mathrm{NaHCO}_{3}$ at $37{ }^{\circ} \mathrm{C}$ with $5 \% \mathrm{CO}_{2}$, with every fourth passage supplemented with $0.5 \mathrm{nM}$ flavopiridol to maintain drug resistance/selection pressure. Cells were grown in 96-well plates at $\sim 50 \%$ confluence and incubated overnight to establish a monolayer. Cells were treated with 40SV nanoparticles diluted in media for $48 \mathrm{~h}$ (quadruplicate wells per treatment). After treatment, cells were incubated for $3 \mathrm{~h}$ in neutral red $\left(33 \mu \mathrm{g} \mathrm{mL}^{-1}\right)$ medium, washed twice with PBS and lysed with $75 \%$ methanol:25\% acetic acid solution. A microplate reader was used to measure the absorbance at $540 \mathrm{~nm}$. The viability of the treated cells was represented as the percentage of the untreated control. The activity of the 40SV nanoparticles was compared to free $\mathrm{Ag}$ present in $\mathrm{AgNO}_{3}$ and to equivalent amounts of unprocessed plant extract.

\section{Drug loading}

Firstly, $5 \mathrm{mg}$ of DOX and DNR was dissolved in $100 \mathrm{~mL}$ water and stirred to prepare individual drug solutions. These solutions were examined between 400 and $600 \mathrm{~nm}$ by UVvisible spectrophotometer for use as control sample ( $0 \mathrm{~min})$. After that, $10 \mathrm{mg} \mathrm{Ag-NPs} \mathrm{was} \mathrm{added} \mathrm{to} \mathrm{each} \mathrm{solution} \mathrm{with}$ particle concentration $100 \mathrm{mg} \mathrm{L}^{-1}$ and kept in an orbital shaker at moderate frequency. The adsorption and concentration behaviors of DOX and DNR were recorded by taking $2.5 \mathrm{~mL}$ of unbound drug supernatant at various time intervals $(30,60,120,240$ and $480 \mathrm{~min}$.) for measuring the drug loading capacity evaluated by UV-visible absorption at $480 \mathrm{~nm}$.

\section{Loading efficiency}

The loading capacity (LC) and loading efficiency (LE) of drugs (DOX, DNR) were calculated by Eqs. (1) (Mashhadizadeh and Diva 2012) and (2) (Mashhadizadeh and Diva 2012; Sabeti et al. 2014), respectively.

LC of $\operatorname{drug}\left(\frac{\mathrm{mg}}{\mathrm{mg}}\right)=\frac{\left(\operatorname{Drug}_{\mathrm{i}}\right)-\left(\operatorname{Drug}_{\mathrm{f}}\right)}{\left(\operatorname{Drug}_{\mathrm{c}}\right)}$,

$\%$ LE of drug $=\frac{\left(\operatorname{Drug}_{\mathrm{i}}\right)-\left(\operatorname{Drug}_{\mathrm{f}}\right)}{\left(\operatorname{Drug}_{\mathrm{i}}\right)} \times 100$.

$\left(\operatorname{Drug}_{\mathrm{i}}\right)$ is the initial amount $(\mathrm{mg})$ of the drug, $\left(\operatorname{Drug}_{\mathrm{f}}\right)$ the free drug that remains in the supernatant and $\left(\operatorname{Drug}_{c}\right)$ the amount (mg) of carrier (Ag-NPs drug cargo).

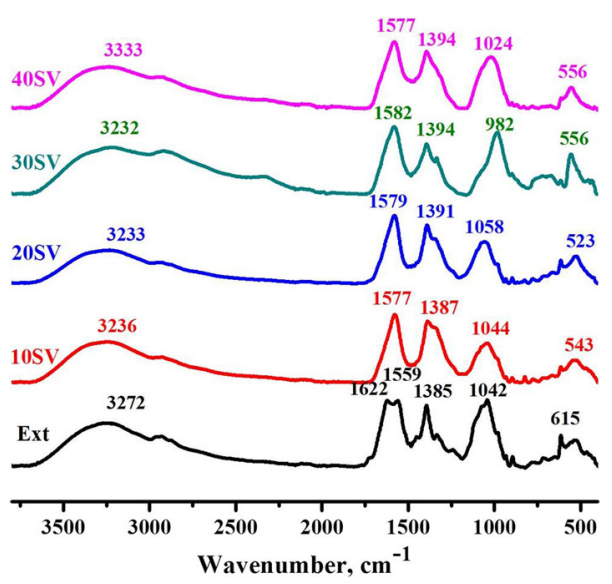

Fig. 3 FTIR spectra of extract and biosynthesized silver nanoparticles with different extract concentrations from $10 \mathrm{vol} \%$ (10 SV) up to 40 vol\% (40 SV) 
Fig. 4 TEM images of biosynthesized silver nanoparticles (a-d) and their corresponding size distribution (e-h) using SV seed extract at different concentrations of $\mathbf{a}, \mathbf{e}$ $10 \mathrm{SV} ; \mathbf{b}, \mathbf{f} 20 \mathrm{SV} ; \mathbf{c}, \mathbf{g} 30 \mathrm{SV}$ and $\mathbf{d}, \mathbf{h} 40 \mathrm{SV}$
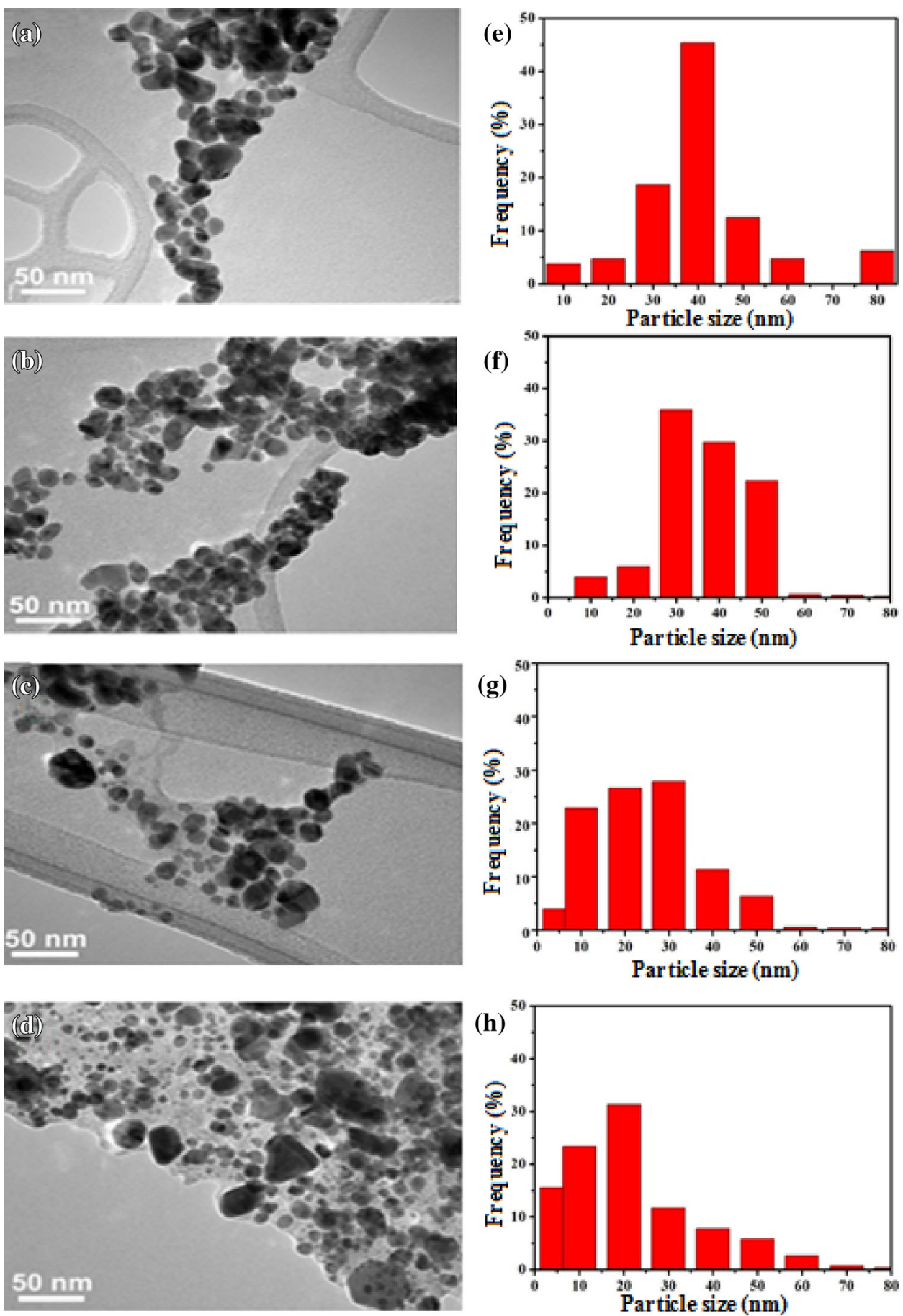

\section{Anthelmintic activity}

In vitro anthelmintic study of Ag-NPs was evaluated in ten Petri dishes containing four adult earthworms each and preserved in phosphate-buffered solution $(50 \mathrm{~mL})$. NPs were used for in vitro trials and each dilution had 6 and $12 \mu \mathrm{g} \mathrm{mL}^{-1}$ separately, while the single dose of levamisole
$\mathrm{HCl} 0.55 \mu \mathrm{g} \mathrm{mL}^{-1}$ acted as a positive control and no treatment was given to a Petri plate which acted as the negative control. The in vitro anthelmintic potential of NPs was determined on the basis of number of dead earthworms after $3 \mathrm{~h}$ of incubation at $37{ }^{\circ} \mathrm{C}$, similar to previous research (Amin et al. 2009). 


\section{Results and discussion}

Figure 2c shows the UV-visible spectra of Ag-NPs synthesized with different concentrations of the seed extract. It can be observed that a broad absorption peak appeared between 350 and $550 \mathrm{~nm}$ after $\mathrm{AgNO}_{3}$ solution reacted with SV. Decreasing the SV concentration from 40 to 10 vol\% shifted the absorption to longer wavelengths, accompanied by a significant decrease in the absorption intensity. This shift and decrease in absorption intensity are well reflected in the sharp change in sample color upon decreasing the SV concentration (Fig. 2a).

The FTIR spectra of the Ag-NPs synthesized at the various SV concentrations was obtained to identify the functional groups present (Fig. 3). This is critical as functional groups not only interact with metal salts, but also play an important role in the nanoparticle synthesis (Babu and Gunasekaran 2009; Bar et al. 2009). The absorbance peak located at $3272 \mathrm{~cm}^{-1}$ corresponds to amine N-H (Velmurugan, et al. 2011) and alcoholic O-H stretching vibrational modes. The peaks at 1622 and $1559 \mathrm{~cm}^{-1}$ suggest the presence of aromatic $-\mathrm{C}=\mathrm{C}$ stretching vibrations, which are usually typical for the amide band of polypeptides. The absorption bands at 1385 , 1042 and $615 \mathrm{~cm}^{-1}$ show the stretching vibration of the amide, alkene group and most probably the $\mathrm{C}-\mathrm{O}$ group of polyols, (Ramamurthy et al. 2013) respectively. Notably, the peaks at $3272,1559,1385,1042$ and $615 \mathrm{~cm}^{-1}$ of the seed extract are shifted in the biosynthesized Ag-NPs. In particular, the peak at $3272 \mathrm{~cm}^{-1}$ of the SV seed exudate shifted to higher wavelength indicating surface binding to Ag-NPs, while the $1622 \mathrm{~cm}^{-1}$ peak shifted to lower wavelength $\left(1577 \mathrm{~cm}^{-1}\right)$ indicating reduction of $\mathrm{AgNO}_{3}$ to Ag-NPs (Ramar et al. 2015). Figure 4a-d shows the representative TEM images of four Ag-NPs batches synthesized with different seed extract concentrations. The size and shape of the particle are influenced by the seed extract concentration. The size of the NPs decreased with increase in the seed extract concentration. At $10 \mathrm{vol} \%$ of the extract, the formation of large NPs of $35 \mathrm{~nm}$ was observed. At 40 vol\%, smaller NPs of $20 \mathrm{~nm}$ were formed. The average particle sizes $\left(d_{\text {TEM }}\right)$ analyzed from count size distribution were 40, 38, 27 and $22 \mathrm{~nm}$, respectively, for samples synthesized at 10-40 SV (Fig. 4). At the same time, the geometric standard variation also ranged from $\sim 40 \mathrm{~nm}$ at $10 \mathrm{vol} \%$ to $\sim 22 \mathrm{~nm}$ at $40 \mathrm{vol} \%$.

EDX analysis was conducted to probe the composition of biosynthesized Ag-NPs. The three characteristic Ag peaks can be observed at approximately 3,22 and $25 \mathrm{keV}$ (Fig. 5). A spectrum at $3 \mathrm{keV}$ is the typical energy value for metallic silver nano crystallites (Magudapathy et al. 2001). In addition, the spectral signatures of carbon and sulfur were also observed, indicating that extracellular biomoieties were adsorbed on the surface or in the vicinity of metal nanoparticles. The $\mathrm{Cu}$ and $\mathrm{Al}$ signals come from the grid and instrument, respectively.

Figure 6 shows the XRD pattern of the Ag-NP powders. A number of Bragg diffraction peaks, indexed as (111), (200), (220) and (311) with corresponding $2 \theta$ values of $38^{\circ}, 44^{\circ}, 64^{\circ}$ and $76^{\circ}$ confirm the crystallinity and the facecentered cubic Ag structure (JCPDS 04-0783) (Priyadharshini et al. 2014). The average crystal size obtained from the Scherrer equation $\left(d_{\mathrm{XRD}}\right)$ was $13.7,9,10.9$ and $10.3 \mathrm{~nm}$ from 10 to $40 \mathrm{SV}$, respectively.

Figure $7 \mathrm{a}, \mathrm{b}$ represents the absorption spectra of hydrophilic anticancer drug (DOX and DNR) supernatants collected at various time intervals (0-480 $\mathrm{min}$ ), and the highest peak intensity of drugs at zero time $(t=0)$ was for the control sample (free from $\mathrm{Ag}-\mathrm{NO}_{3}$ ). Absorbance of anticancer drugs decreases with the passage of time due to adsorption of drug on the surface of Ag-NP. The maximum amount of drug is adsorbed after $480 \mathrm{~min}$. Figure $8 \mathrm{a}$ illustrates the relevant absorption of drugs. There is a rapid decrease in the first $30 \mathrm{~min}$ due to availability of large surface area, high adsorption capacity and fast adsorption

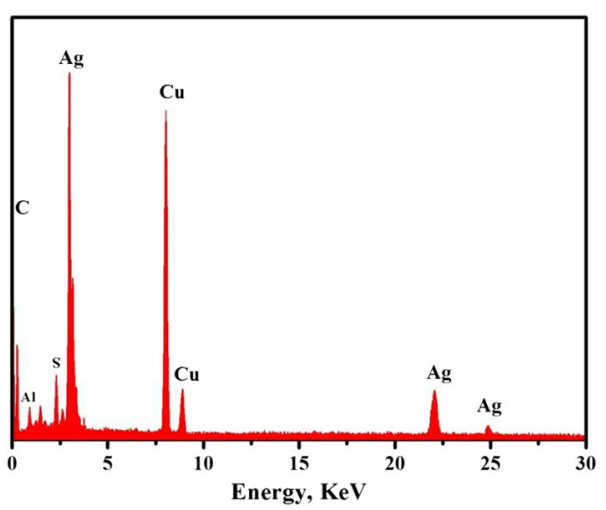

Fig. 5 EDX of Ag-NPs prepared with SV seed extract

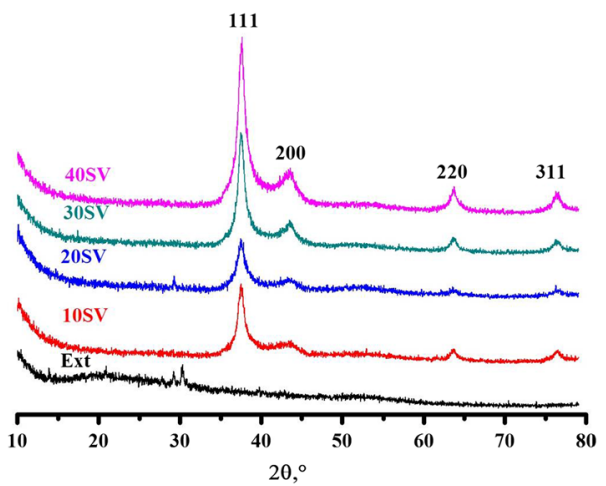

Fig. 6 XRD patterns of extract and biosynthesized Ag-NPs with different concentrations of seed extract from 10 vol\% up to $40 \mathrm{vol} \%$ (40 SV) 

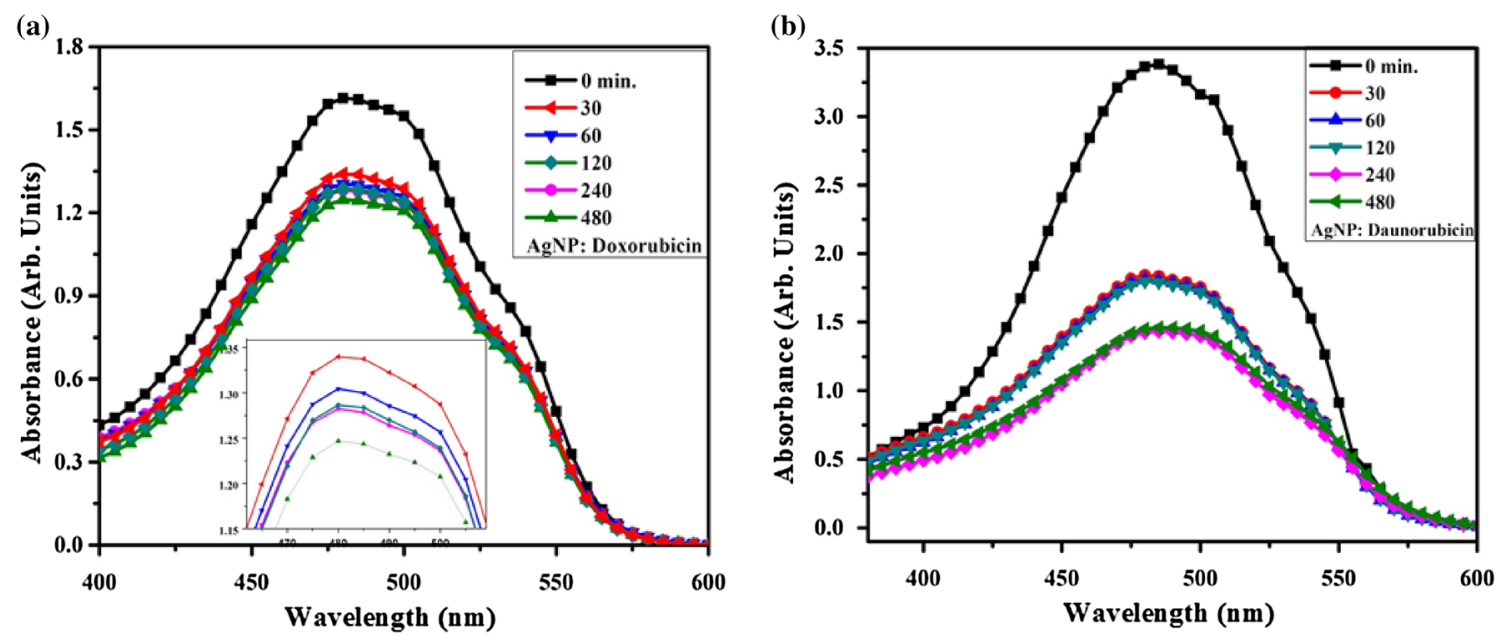

Fig. 7 Absorption spectra of a DOX and b DNR for various contact time ranges from 0 to $480 \mathrm{~min}$

rate of ACD on Ag-NP. The possible mechanisms involved are as follows: (a) The electrostatic interaction of negatively charged bio-moieties on the surface of Ag-NP can easily attract the positively charged ACD molecules adsorbed onto the surface of NPs (Lin and Xing 2008a, b).

(b) There is hydrogen bonding due to a variety of oxygen-containing functional groups present in phytosynthesized Ag-NPs such as $-\mathrm{C}=\mathrm{O},-\mathrm{COOH}$ and $-\mathrm{OH}$. These functional groups make Ag-NPs more suitable for the adsorption of comparatively low molecular weight compounds (Lin and Xing 2008a, 2008b), because the hydrogen bonding between ACD and Ag-NP may occur in four ways: (1) $-\mathrm{COOH}$ of Ag-NPs and -OH of ACD; (2) $\mathrm{COOH}$ of Ag-NPs and $-\mathrm{NH}_{2}$ of ACD; (3) $-\mathrm{OH}$ of Ag-NPs and $-\mathrm{OH}$ of drugs; and (4) $-\mathrm{OH}$ of $\mathrm{Ag}-\mathrm{NPs}$ and $-\mathrm{NH}_{2}$ of ACD (Depan et al. 2011).

Figure $8 \mathrm{~b}$ depicts the efficiency of DOX and DNR after 480 min. DOX showed relatively low absorption (45\%) as compared to DNR (77.5\%). However, DOX presented high loading efficiency and loading capacity of $55 \%(550 \mathrm{mg}$ $\left.\mathrm{g}^{-1}\right)$ and $27.5 \%\left(275 \mathrm{mg} \mathrm{g}^{-1}\right)$ relative to DNR, $22.5 \%$ (225 $\mathrm{mg} \mathrm{g}^{-1}$ ) and $11.25 \%$ (112.5 $\mathrm{mg} \mathrm{g}^{-1}$ ) (Teo et al. 2017).
Fig. 8 a Relative absorption, b loading capacity and c comparison of LC and LE for DOX and DNR
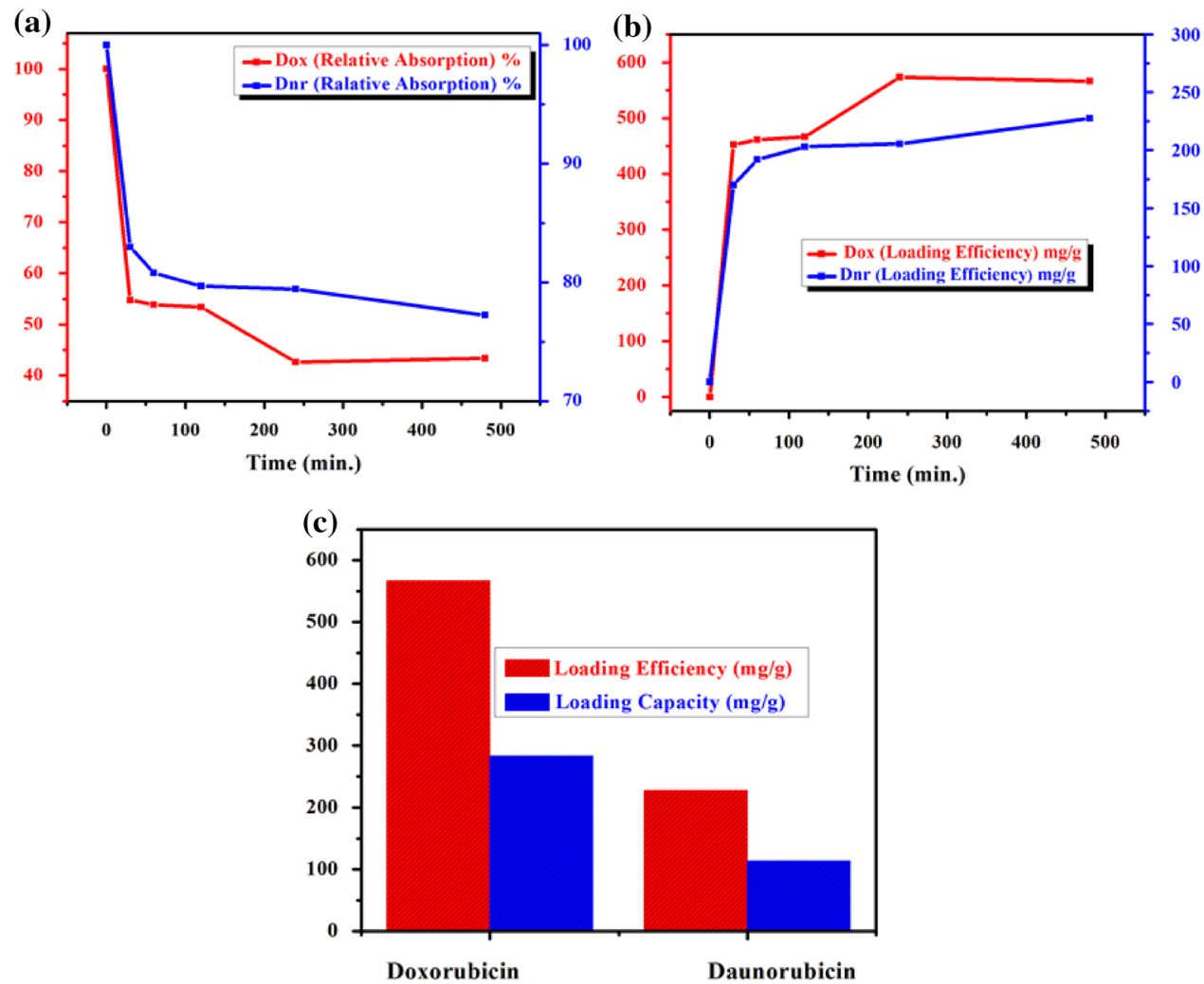

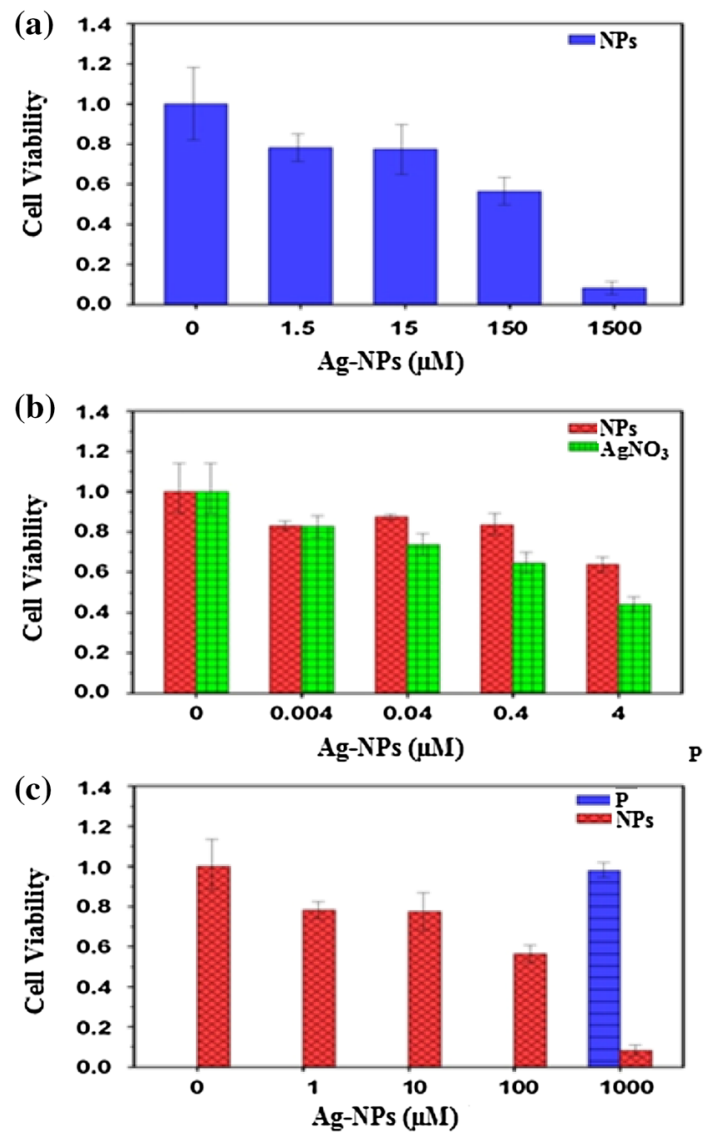

Fig. 9 Effect of Ag-NPs, $\mathrm{AgNO}_{3}$ and plant extract on cell viability of MCF7-FLV breast cancer cells measured by neutral red uptake assay. a Cells were treated with Ag-NPs at various concentrations $(0-1500 \mu \mathrm{M})$ of Ag-NPs. b Comparative analysis of equimolar concentrations of $\mathrm{Ag}$ present as either $\mathrm{Ag}-\mathrm{NPs}$ or $\mathrm{AgNO}_{3}$ against breast cancer cells. c Effect of equivalent amounts of plant extract present as Ag-NPs or plant extract on MCF7-FLV cells $(0-1000 \mu \mathrm{M}$ plant extract equivalents). The results are expressed as the mean \pm SD of one experiment, representative of two separate experiments
The DOX- and DNR-loaded Ag-NPs showed efficient and remarkable loading efficiency $(55,22.5) \%$ and capacity $(27.5,11.25) \%$, respectively

In the current study, the cytotoxicity of $40 \mathrm{SV}-\mathrm{Ag}-\mathrm{NPs}$ was also evaluated on MCF7-FLV breast cancer cells in vitro by the neutral red method. The synthesized Ag-NPs of size 5-20 nm had a dose-dependent cytotoxic effect. Figure $9 \mathrm{a}-\mathrm{c}$ represents three different experiments. Various concentrations of colloidal nanoparticle were treated against MCF7-FLV, showing $\mathrm{IC}_{50}$ at $136 \mu \mathrm{M}$ Ag-NPs as in Fig. 9a (Satapathy et al. 2013). Figure 9b represents the comparative analysis of molar-equivalent $\mathrm{Ag}$ as either $\mathrm{Ag}$ NPs- or $\mathrm{AgNO}_{3}$-indicated toxicity in a concentration-dependent manner. Cell viability is reduced by $50 \%$ when treated with $\mathrm{AgNO}_{3}$ and $35 \%$ with $\mathrm{Ag}-\mathrm{NPs}$ at the concentration of $4 \mu \mathrm{M}$ silver nanoparticles, indicating that unpackaged $\mathrm{Ag}$ is more cytotoxic than the nanoparticles. $\mathrm{NaNO}_{3}$ at the same concentrations did not show any cytotoxicity (data not shown). The relative cytotoxic effect of Ag-NPs and equivalent amounts of plant extract on MCF7-FLV cells $(0-1000 \mu \mathrm{M})$ was examined. The plant extract did not cause any significant growth inhibition in the cells, but SV-Ag-NPs had $\mathrm{IC}_{50}$ at $18 \mu \mathrm{g} \mathrm{mL}^{-1}$ and cell viability was reduced by $90 \%$ at $100 \mu \mathrm{g} \mathrm{mL}^{-1} \mathrm{Ag-NPs}$.

Ag-NPs synthesized with Coleus amboinicus extracts induced toxicity at 30 and $50 \mu \mathrm{g} \mathrm{mL}^{-1}$ respectively, to EAC cell lines indicating concentration-dependent cytotoxicity (Subramanian and Suja 2012). Ag-NPs (9-32 nm) had dose-dependent toxic effects on prostate cancer (PC-3) cells, $\approx 50 \%$ of cells died at $5-10 \mu \mathrm{g} \mathrm{mL}-1$ and IC50 was $>10 \mu \mathrm{g} \mathrm{mL}^{-1}$ (Firdhouse and Lalitha 2013; He et al. 2016). The size and dose of Ag-NP involved in the test played important roles on their toxicity (Carlson 2008; Söderstjerna 2014). Small size nanoparticles of Setaria verticillata, Potentilla fulgens, G. neo-japonicum and

Table 1 Comparative analysis of plant-derived Ag-NPs on cancer cells

\begin{tabular}{|c|c|c|c|c|c|}
\hline Plant-derived Ag-NPs & Cell line & $\mathrm{IC} 50 \mu \mathrm{g} \mathrm{mL}^{-1}$ & IC50 $\mu \mathrm{M}$ & Size & Refs. \\
\hline Setaria verticillata & MCF7-FLV & 18 & 136 & $5-20$ & Current work \\
\hline Potentilla fulgens & MCF-7 & 4.91 & & $10-15$ & Mittal et al. (2015) \\
\hline Potentilla fulgens & U-87 & 8.23 & & $10-15$ & Mittal et al. (2015) \\
\hline Coleus amboinicus & EAC & 30 & & 25.83 & Subramanian and Suja (2012) \\
\hline G. neo-japonicum & MDA-MB-231 & 6 & & $5-8$ & John (2013) \\
\hline Dimocarpus longan & PC-3 & 10 & & $9-32$ & $\begin{array}{l}\text { Firdhouse and Lalitha (2013), } \\
\text { He et al. (2016) }\end{array}$ \\
\hline Starch & HCT116 & & 150 & 142 & Satapathy et al. (2013) \\
\hline Artemisia princeps & A549 cells & 18 & & 20 & Gurunathan et al. (2015) \\
\hline Artemisia princeps & L132 & 50 & & 20 & Gurunathan al. (2015) \\
\hline Origanum vulgare & A549 & 100 & & 136 & Sankar et al. (2013) \\
\hline Gelidiella $\mathrm{sp}$. & Hep-2 & 31.25 & & $40-50$ & Devi et al. (2012) \\
\hline
\end{tabular}


Table 2 Mortality percentage of Ag-NPs against adult earth worms

\begin{tabular}{|c|c|c|c|c|c|}
\hline Plant derived Ag-NPs & Concentration & $\%$ Mortality (1 h) & $\%$ Mortality $(2 \mathrm{~h})$ & $\%$ Mortality (3 h) & $P$ value \\
\hline $10 \mathrm{SV}$ & $6 \mu \mathrm{g} \mathrm{mL}^{-1}$ & 0 & 0 & 0 & \\
\hline $10 \mathrm{SV}$ & $12 \mu \mathrm{g} \mathrm{mL}^{-1}$ & 0 & 25 & 25 & \\
\hline $20 \mathrm{SV}$ & $6 \mu \mathrm{g} \mathrm{mL}^{-1}$ & 0 & 25 & 25 & \\
\hline $20 \mathrm{SV}$ & $12 \mu \mathrm{g} \mathrm{mL}^{-1}$ & 25 & 25 & 25 & \\
\hline $30 \mathrm{SV}$ & $6 \mu \mathrm{g} \mathrm{mL}^{-1}$ & 25 & 50 & 50 & $P<0.05$ \\
\hline $30 \mathrm{SV}$ & $12 \mu \mathrm{g} \mathrm{mL}^{-1}$ & 50 & 100 & 100 & \\
\hline $40 \mathrm{SV}$ & $6 \mu \mathrm{g} \mathrm{mL}^{-1}$ & 50 & 100 & 100 & \\
\hline $40 \mathrm{SV}$ & $12 \mu \mathrm{g} \mathrm{mL}^{-1}$ & 50 & 100 & 100 & \\
\hline+ ve $\mathrm{C}$ & $0.55 \mu \mathrm{g} \mathrm{mL}^{-1} \mathrm{HCl}$ & 50 & 100 & 100 & \\
\hline- ve $\mathrm{C}$ & Phosphate buffer & 0 & 0 & 0 & \\
\hline
\end{tabular}

Dimocarpus longan show more toxicity than large nanoparticles in Table 1.

The in vitro anthelmintic potential of biosynthesized Ag-NPs was studied in adult earthworms (Lumbricina). This resulted in a statistically significant effect $(P<0.05)$ in Table 2. The $40 \mathrm{SV}$ sample shows $50 \%$ mortality of earthworms after $1 \mathrm{~h}$ and $100 \%$ mortality after $2-3 \mathrm{~h}$. The $30 \mathrm{SV}$ samples are more effective at $12 \mu \mathrm{g} \mathrm{mL}^{-1}$ concentration compared to $6 \mu \mathrm{g} \mathrm{mL}^{-1}$, while both $10 \mathrm{SV}$ and 20 SV samples show $25 \%$ mortality of earthworms after 2-3 h. However, this work reveals the cytotoxic effect of NP against the soil organism, Lumbricina, and recommends that proper disposal of the NPs to the environment needs to be planned (Samrot et al. 2017).

\section{Conclusion}

In this work, we presented a green method for the biosynthesis of Ag-NPs using seed extract. The physiochemical properties of the resulting silver NPs were characterized as a function of the SV seed extract concentration. Increasing the SV concentrations significantly reduced the NP size. It was found that its toxicity strongly depended on the concentration of SV seed extract. Their toxicity was evaluated using MCF7-FLV cell lines and adult Lumbricina. It was observed that the cytotoxicity of silver nanoparticles increased with increase in the seed extract concentration. The DOX- and DNR-loaded Ag-NPs showed efficient and remarkable loading efficiency (80, $50) \%$ and capacity $(40,25) \%$, respectively, dependent on electrostatic interaction, surface morphology, H-bonding and ion exchange interaction between ADC and Ag-NPs.

Acknowledgements This work was supported by the Higher Education Commission (HEC), Pakistan, through 5000 indigenous $\mathrm{PhD}$ Scholar Program. The microscope analyses were conducted in the ANU Center for Advanced Microscopy (CAM).

\section{Compliance with ethical standards}

Conflict of interest The authors confirm that they have no conflict of interest.

Open Access This article is distributed under the terms of the Creative Commons Attribution 4.0 International License (http:// creativecommons.org/licenses/by/4.0/), which permits unrestricted use, distribution, and reproduction in any medium, provided you give appropriate credit to the original author(s) and the source, provide a link to the Creative Commons license, and indicate if changes were made.

\section{References}

Amin M, Mostofa M, Hoque M, Sayed M (2009) In vitro anthelmintic efficacy of some indigenous medicinal plants against gastrointestinal nematodes of cattle. JBAU 7(1):57-61. doi:10.3329/ jbau.v7i1.4799

Azeez L, Lateef A, Adebisi SA (2017) Silver nanoparticles (AgNPs) biosynthesized using pod extract of Cola nitida enhances antioxidant activity and phytochemical composition of Amaranthus caudatus. Linn Appl Nanosci 7:59-66. doi:10.1007/s13204017-0546-2

Babu MG, Gunasekaran P (2009) Production and structural characterization of crystalline silver nanoparticles from Bacillus cereus isolate. Colloids Surf B Biointerfaces 74(1):195. doi:10.1016/j. colsurfb.2009.07.016

Bar H, Bhui DK, Sahoo GP, Sarkar P, Pyne S, Misra A (2009) Green synthesis of silver nanoparticles using seed extract of Jatropha curcas. Colloids Surf A Physicochem Eng Asp 348(1):212-216. doi:10.1016/j.colsurfa.2009.07.021

Carlson C, Hussain SM, Schrand AM, Braydich-Stolle LK, Hess KL, Jones RL, Schlager JJ (2008) Unique cellular interaction of silver nanoparticles: size-dependent generation of reactive oxygen species. J Phys Chem B 112(43):13608-13619. doi:10. $1021 /$ jp712087m

Daunorubicin (2017) https://commons.wikimedia.org/wiki/File: Daunorubicin.svg. https://commons.wikimedia.org/wiki/File: Daunorubicin_ball-and-stick.png

Devi JS, BhimbA BV, Ratnam K (2012) Invitro anticancer activity of silver nanoparticles synthesized using the extract of Gelidiella sp. Int J Pharm Pharm Sci 4:710-715

Depan D, Shah J, Misra RDK (2011) Controlled release of drug from folate-decorated and grapheme mediated drug delivery system: 
synthesis, loading efficiency, and drug release response. Mater Sci Eng C 31:1305-1312. doi:10.1016/j.msec.2011.04.010

Doxorubicin (2017) https://commons.wikimedia.org/wiki/File: Doxorubicin_3D_ball.png. https://commons.wikimedia.org/ wiki/File:Doxorubicin2DCSD.svg

Firdhouse MJ, Lalitha P (2013) Biosynthesis of silver nanoparticles using the extract of Alternanthera sessilis - antiproliferative effect against prostate cancer cells. Cancer Nanotechnol 4(6):137. doi:10.1007/s12645-013-0045-4

Gurunathan S, Jeong JK, Han JW, Zhang XF, Park JH, Kim JH (2015) Multidimensionaleffects of biologically synthesized silver nanoparticles in Helicobacter pylori, Helicobacter felis, and human lung (L132) and lung carcinoma A549 cells. Nanoscale Res Lett 10(1):35. doi:10.1186/s11671-015-0747-0

He Y, Du Z, Ma S, Cheng S, Jiang S, Liu Y, Li D, Huang Zhang K, Zheng X (2016) Biosynthesis, antibacterial activity and anticancer effects against prostate cancer (PC-3) cells of silver nanoparticles using Dimocarpus Longan Lour. Nanoscale Res Lett 11(1):1-10. doi:10.1186/s11671-016-1511-9

Holm LG, Plucknett DL, Pancho JV, Herberger JP (1977) The world's worst weeds. University Press, Cambridge

Ismail RA, Almashhadani NJ, Sadik RH (2017) Preparation and properties of polystyrene incorporated with gold and silver nanoparticles for optoelectronic applications. Appl Nanosci 7:109-116. doi:10.1007/s13204-017-0550-6

Jagtap UB, Bapat VA (2013) Green synthesis of silver nanoparticles using Artocarpus heterophyllus Lam. seed extract and its antibacterial activity. Ind Crops Prod 46:132-137. doi:10.1155/ 2013/201057

John P (2013) Green synthesis of silver nanoparticles using Ganoderma neo-japonicum Imazeki: a potential cytotoxic agent against breast cancer cells. Int J Nanomed 8:4399-4413. doi:10.2147/IJN.S51881

Khan AV, Ahmed QU, Mir MR, Shukla I, Khan AA (2011) Antibacterial efficacy of the seed extracts of Melia azedarach against some hospital isolated human pathogenic bacterial strains. Asian Pac J Trop Biomed 1(6):452-455. doi:10.1016/ S2221-1691(11)60099-3

Kokina I, Gerbreders V, Sledevskis E, Bulanovs A (2013) Penetration of nanoparticles in flax (Linum usitatissimum L.) calli and regenerants. J Biotechnol 165(2):127-132. doi:10.1016/j.jbiotec. 2013.03.011

Krishna IM, Reddy GB, Veerabhadram G, Madhusudhan A (2016) Eco-friendly green synthesis of silver nanoparticles using Salmalia malabarica: synthesis, characterization, antimicrobial, and catalytic activity studies. Appl Nanosci 6(5):681-689. doi:10.1007/s13204-015-0479-6

Lade BD, Patil AS (2017) Silver nano fabrication using leaf disc of Passiflora foetida Linn. Appl Nanosci 7:181-192. doi:10.1007/ s13204-017-0558-y

Lee KS, El-Sayed MA (2006) Gold and silver nanoparticles in sensing and imaging: sensitivity of plasmon response to size, shape, and metal composition. J Phys Chem B 110(39):19220-19225. doi:10.1021/jp062536y

Lin D, Xing B (2008a) Adsorption of phenolic compounds by carbon nanotubes: role of aromaticity and substitution of hydroxyl groups. Environ Sci Technol 42:7254-7259. doi:10.1021/ es801297u

Lin D, Xing B (2008b) Adsorption of phenolic compounds by carbon nanotubes: role of aromaticity and substitution of hydroxyl groups. Environ Sci Technol 42:9005-9013. doi:10.1021/ es801777n

Lukman AI, Gong B, Marjo CE, Roessner U, Harris AT (2011) Facile synthesis, stabilization, and anti-bacterial performance of discrete $\mathrm{Ag}$ nanoparticles using Medicago sativa seed exudates.
J Colloid Interface Sci 353(2):433-444. doi:10.1016/j.jcis.2010. 09.088

Magudapathy PP, Gangopadhyay Panigrahi B, Nair K, Dhara S (2001) Electrical transport studies of Ag nanoclusters embedded in glass matrix. Phys B Condens Matter 299(1):142-146. doi:10. 1016/S0921-4526(00)00580-9

Mashhadizadeh MH, Diva MA (2012) Drug-carrying amino silane coated magnetic nanoparticles as potential vehicles for delivery of antibiotics. J Nanomed Nanotechol 3:7. doi:10.4172/21577439.1000139

Mittal AK, Tripathy D, Choudhary A, Aili PK, Chatterjee A, Singh IP, Banerjee UC (2015) Bio-synthesis of silver nanoparticles using Potentilla fulgens Wall. ex Hook. and its therapeutic evaluation as anticancer and antimicrobial agent. Mater Sci Eng C 53:120-127. doi:10.1016/j.msec.2015.04.038

Nair LS, Laurencin CT (2007) Silver nanoparticles: synthesis and therapeutic applications. JBN 3(4):301-316. doi:10.1166/jbn. 2007.041

Navaladian S, Viswanathan B, Viswanath R, Varadarajan T (2007) Thermal decomposition as route for silver nanoparticles. Nanoscale Res Lett 2(1):44. doi:10.1007/s11671-006-9028-2

Priyadharshini RI, Prasannaraj G, Geetha N, Venkatachalam P (2014) Microwave-mediated extracellular synthesis of metallic silver and zinc oxide nanoparticles using macro-algae (Gracilaria edulis) extracts and its anticancer activity against human PC3 cell lines. Biotechnol Appl Biochem 174(8):2777-2790. doi:10. 1007/s12010-014-1225-3

Ramamurthy C, Padma M, Mareeswaran R, Suyavaran A, Kumar MS, Premkumar K, Thirunavukkarasu C (2013) The extra cellular synthesis of gold and silver nanoparticles and their free radical scavenging and antibacterial properties. Colloids Surf B Biointerfaces 102:808-815. doi:10.1016/j.colsurfb.2012.09.025

Ramar M, Manikandan B, Marimuthu PN, Raman T, Mahalingam A, Subramanian P, Karthick S, Munusamy A (2015) Synthesis of silver nanoparticles using Solanum trilobatum fruits extract and its antibacterial, cytotoxic activity against human breast cancer cell line MCF 7. Spectrochim Acta A Mol Biomol Spectrosc 140:223-228. doi:10.1016/j.saa.2014.12.060

Sabeti B, Noordin MI, Mohd S, Hashim R, Dahlan A, Javar HA (2014) Development and characterization of liposomal doxorubicin hydrochloride with palm oil. BioMed Res Int Hindawi Publ Corp. doi:10.1155/2014/765426

Samrot AV, Justin C, Padmanaban S, Burman U (2017) A study on the effect of chemically synthesized magnetite nanoparticles on earthworm: Eudrilus eugeniae. Appl Nanosci 7:17-23. doi:10. 1007/s13204-016-0542-y

Sankar R, Karthik A, Prabu A, Karthik S, Shivashangari KS, Ravikumar V (2013) Origanum vulgare mediated biosynthesis of silver nanoparticles for its antibacterial and anticancer activity. Colloids Surf B Biointerfaces 108:80-84. doi:10.1016/ j.colsurfb.2013.02.033

Satapathy SR, Mohapatra P, Preet R, Das D, Sarkar B, Choudhuri T, Wyatt MD, Kundu CN (2013) Silver-based nanoparticles induce apoptosis in human colon cancer cells mediated through p53. Nanomedicine 8(8):1307-1322. doi:10.2217/nnm.12.176

Sharma G, Jeevanandam P (2013) A facile synthesis of multifunctional iron oxide@ Ag core-shell nanoparticles and their catalytic applications. Eur J Inorg Chem 36:6126-6136. doi:10. 1002/ejic.201301193

Sims RW, Gerard BM (1985) Earthworms: keys and notes for the identification and study of the species. Brill Archive, Leiden

Smetana AB, Klabunde KJ, Sorensen CM (2005) Synthesis of spherical silver nanoparticles by digestive ripening, stabilization with various agents, and their 3-D and 2-D superlattice formation. J. Colloid. Interface Sci 284(2):521-526. doi:10. 1016/j.jcis.2004.10.038

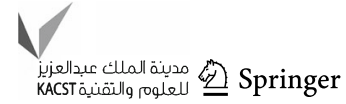


Söderstjerna E, Bauer P, Cedervall T, Abdshill H, Johansson F, Johansson UE (2014) Silver and gold nanoparticles exposure to in vitro cultured retina-studies on nanoparticle internalization, apoptosis, oxidative stress, glial-and microglial activity. PLoS One 9(8):e105359. doi:10.1371/journal.pone.0105359

Subramanian V, Suja S (2012) Green synthesis of silver nanoparticles using Coleus amboinicus lour, antioxidant activity and in vitro cytotoxicity against Ehrlich's ascite carcinoma. J Pharm Res $5(2): 3-1272$

Teo JY, Chin W, Ke X, Gao S, Liu S, Cheng W, Hedrick JL, Yang YY (2017) $\mathrm{pH}$ and redox dual-responsive biodegradable polymeric micelles with high drug loading for effective anticancer drug delivery. Nanomedicine 13:431. doi:10.1016/j.nano.2016. 09.016

Tolaymat TM, El Badawy AM, Genaidy A, Scheckel KG, Luxton TP, Suidan M (2010) An evidence-based environmental perspective of manufactured silver nanoparticle in syntheses and applications: a systematic review and critical appraisal of peer-reviewed scientific papers. Sci Total Environ 408((5):999-1006. doi:10. 1016/j.scitotenv.2009.11.003

Upendra KS, Amita V, Sunil KP, Himanshu P, Avinash CP (2015) In vitro, in vivo and pharmacokinetic assessment of amikacin sulphate laden polymeric nanoparticles meant for controlled ocular drug delivery. Appl Nanosci 5:143-155. doi:10.1007/ s13204-014-0300-y

Velmurugan P, Shim J, Kamala-Kannan S, Lee KJ, Oh BT, Balachandar V (2011) Crystallization of silver through reduction process using Elaeis guineensis biosolid extract. Biotechnol Prog 27(1):273-279. doi:10.1002/btpr.511

Yu D-G (2007) Formation of colloidal silver nanoparticles stabilized by $\mathrm{Na}+$-poly ( $\gamma$-glutamic acid)-silver nitrate complex via chemical reduction process. Colloids Surf B 59(2):171-178

Zamiri R, Zakaria A, Abbastabar H, Darroudi M, Husin MS, Mahdi MA (2011) Laser-fabricated castor oil-capped silver nanoparticles. Int J Nanomed 6:565-568. doi:10.2147/IJN.S16384

Zhang J, Gu M, Zheng T, Zhu J (2009) Synthesis of Gelatin-stabilized gold nanoparticles and assembly of carboxylic single-walled carbon nanotubes/Au composites for cytosensing and drug uptake. Anal Chem 81:6641-6664. doi:10.1021/ac900628y

Zhang J, Cheng F, Lib J, Zhub J, Lu Y (2016) Fluorescent nanoprobes for sensing and imaging of metal ions: recent advances and future perspectives. Nanotoday 11:309-329. doi:10.1016/j. nantod.2016.05.010

Zhang J, Cheng F, Zheng T, Zhu J (2017) Versatile aptasensor for electrochemical quantification of cell surface glycan and nakedeye tracking glycolytic inhibition in living cells. Biosens Bioelectron 89:937-945. doi:10.1016/j.bios.2016.09.087

\section{Publisher's Note}

Springer Nature remains neutral with regard to jurisdictional claims in published maps and institutional affiliations. 